\title{
Voluntary Rescue Service in Hungary: The HUSZÁR Team
}

\author{
Tamás HÁBERMAYER, ${ }^{1}$ Péter HORVÁTH²
}

\begin{abstract}
HUSZÁR, the Hungarian National Organisation for Rescue Services, was founded in 2012 and now has a staff of over 80. HUSZÁR is a special rescue unit that can be deployed in domestic and international disaster management. Based on the United Nations International Search and Rescue Advisory Group (UN INSARAG) classification, HUSZÁR is a medium level urban search and rescue team and its units are equipped with special skills and technical equipment. A special feature of the team is volunteerism combined with professional interventional skills. Its subunits can manage individual interventions, they have participated in several international disaster relief tasks following earthquakes and tsunamis, and they have also played an active role in the preparation of other nations' rescue teams.
\end{abstract}

Keywords: HUSZÁR, INSARAG, Hungary, voluntary rescue team.

\section{Introduction}

When a disaster occurs, the arrangement and performance of rescue operations as well as the management of the consequences place a significant burden on the defences of the affected country. Such situations require considerable mobilisation, high-level coordination of tasks and optimal distribution of the available resources. The efficient performance of all these tasks is dependent on the timely detection of imminent threats, prudent planning and properly trained forces that are skilled in aversion. Certain disasters (e.g. flood, excessive ground water at familiar or expected locations) can be managed with traditional precautions and planning; however, there are some extraordinary events that are almost impossible to prepare for (e.g. a new, unprecedented type of disaster or an earthquake whose magnitude is unpredictable). Such events can be managed by a novel type of hazard planning that is based on capabilities and expert networks and whose aim is to develop adaptability and rapid reactions. The inclusion of voluntary rescue teams is an essential improvement of threefold significance. Firstly, it is the local citizens who perform the very first intervention at the site of the disaster. They are present in the close proximity of the event, thus if they are not affected by the disaster, they can perform some immediate rescue operations. Following an earthquake, they can for instance search for survivors in the collapsed buildings and provide

\footnotetext{
$1 \quad$ Ph.D. student, National University of Public Service, National Directorate General for Disaster Management; e-mail: tamas.habermayer@katved.gov.hu; ORCID: https://orcid.org/0000-0002-6677-9163

2 Ph.D. student, National University of Public Service, National Directorate General for Disaster Management; e-mail: peter.horvath2@katved.gov.hu; ORCID: https://orcid.org/0000-0001-7595-7980
} 
first aid. Residents can be prepared for local hazards; therefore, they can effectively assist professional rescue teams. Another important consideration is local knowledge. People who are familiar with the affected area can significantly increase the efficiency of interventions if they cooperate with those involved in disaster relief. Even if we consider these two factors alone, the role of volunteers is obvious. The third consideration is specific: there are professional types of interventions (e.g. dog search, diving, cave and alpine rescue), which, if offered as voluntary services, can markedly support the efforts of official forces. However, the equipment and preparedness of voluntary teams cannot be taken for granted as there can be marked differences between individual organisations. In view of their equipment and skills, some voluntary teams are only prepared for the aversion of local threats, while more professional, skilled organisations can serve national or even international purposes. As regards international search and rescue, the guidelines of INSARAG were endorsed by the United Nations General Assembly Resolution 57/150. [1] The voluntary Urban Search and Rescue (USAR) team of Hungary, called HUSZÁR, has recently been re-classified in accordance with the INSARAG guidelines, so this paper is going to examine the highest professional level. In view of the skills and capabilities of its subunits, the team can be considered a professional organisation in the field of earthquake-related search and rescue tasks.

However, the question is how a team of volunteers can meet the professional requirements set by UN INSARAG concerning urban search and rescue even if they are coordinated and supported by the government.

Therefore, the aim of this paper is to introduce HUSZÁR, the Hungarian urban search and rescue team, its special features and versatility; the team which could fulfil the requirements of the international qualification system.

As part of our research, we contacted the heads of the rescue subunits, analysed the composition of the team, the qualifications of the members as well as the versatility of the technical equipment. Previous interventions of the member organisations were also investigated and we reviewed how a complex unit can be established by combining several voluntary organisations.

\section{The HUSZÁr Rescue Team}

The voluntary rescue team of Hungary, HUSZÁR, was classified as a medium USAR team in 2012, when it successfully met the professional requirements of the UN at an international field exercise and classification in Hajdúszoboszló, Hungary. The official rescue team of the country, HUNOR, received its classification at the same time, thus Hungary is one of the few countries that has two rescue teams with a UN INSARAG qualification.

Since 2012 the HUSZÁR team has participated in several successful interventions, which mostly dealt with floods and excessive ground water, as these phenomena are the most frequent hazardous events caused by natural processes in Hungary and the neighbouring countries. The affiliated organisations of the team have also participated separately in disaster relief operations following earthquakes, tsunamis, and other natural disasters in Europe, Asia and Africa, which highlights the professionalism of the team. 
Hungarian Act No. CXXVIII of 2011 concerning disaster management [2] provides the following definition of voluntary rescue teams: "A voluntary civil society organisation with specially trained members and professional equipment established for the prevention and relief of natural disasters or hazardous events, performance of disaster management tasks and minimisation of human loss and suffering."

The subunits of the HUSZÁR has met the requirements of the National Classification, ${ }^{3}$ so all of them belong to registered voluntary rescue organisations.

Since its classification, the team has taken part in several field exercises and trainings, all of which have contributed to its development. The professional skills of the team have become broader and its technical equipment has been developed to meet modern challenges. We can state that its present preparedness fits the revised UN INSARAG guidelines and it could be put into action on each and any day of the year.

\section{Meeting International Guidelines}

INSARAG has more than 90 countries and international organisations in its ranks. Every accepted member belongs to this branch of the United Nations. The most important aim is to develop most effective methods and techniques to be employed in earthquake response and to coordinate the activity of those who take part in the rescue. The guidelines required for urban search and rescue preparedness and interventions were compiled by the countries and international organisations that belong to the network of INSARAG. The guidelines were based on all the experience gained from interventions performed since its establishment, so they comprise the highest level disaster management methods. The observation and application of these guidelines enables the cooperation of international organisations and rescue teams from various countries by following the same principles and regulations, and the coordination of the rescue tasks can also be realised at a high level. The adoptable and professional nature of the INSARAG guidelines, together with the positive, stimulating effect they had on the disaster management system of the individual countries, as well as the quality assurance (classification and monitoring) all make INSARAG one of the most developed international systems, but it may well be the most developed one.

The INSARAG classification defines three levels of capacity for USAR teams (lightmedium-heavy). HUNOR is classified as a heavy, while HUSZÁR as a medium team. Medium and heavy USAR teams have the ability to conduct technical or dog search and rescue operations in collapsed or failed structures to look for humans and they have the technical equipment to lift and move heavy objects. The staff can pull down, cut, reinforce or support concrete and structural steel typically used for construction, work with alpine techniques, detect, identify and isolate hazardous substances. The medical staff can perform resuscitation, amputation and can provide life support. The rescue teams must be adequately staffed and logistically sufficient to allow for 24-hour operations at a single intervention site for 5-10 days (light-5, medium-7 and heavy-10). [3]

3 Voluntary rescue teams have to acquire a classification in order to ensure the authenticity of their organisation, the professional nature of their interventions, and also to create an effective base for cooperation with the national disaster management forces. For more details (in Hungarian) see: https://katasztrofavedelem.hu/26431/ nemzeti-minositesi-rendszer (Downloaded: 12.02.2020) 


\section{HUSZÁR Subunits}

"Disaster management is a national issue. A unified command of defence is governmental responsibility. All citizens have the right to learn about the potential hazards in their environment and familiarise themselves with the rules of prevention. It is also their right and duty to take part in disaster management.” [2: para 1 (1)]

HUSZÁR is a medium urban search and rescue team composed of voluntary subunits of special classification. Its staff belong to voluntary rescue organisations that have been classified and registered by the National Classification of Hungary. The units have a cooperation agreement with the Directorate General for Disaster Management, Ministry of Interior, Hungary (in Hungarian: Belügyminisztérium, Országos Katasztrófavédelmi Főigazgatóság - BM OKF). The combined force of the units, HUSZÁR, is a medium USAR team classified by INSARAG. Professional command and notification of deployment are performed by the regional representatives of BM OKF, who are almost always voluntary members of the units.

HUSZÁR is composed of six classified units, that can be deployed individually to assist with domestic disaster management. The units are the following:

- Pilisvörösvár Volunteer Firefighters (in Hungarian: Pilisvörösvári Önkéntes Tűzoltó Egyesület - Pilis ÖTE); ${ }^{4}$

- Pest County Search and Rescue Team (in Hungarian: Pest Megyei Kutató-Mentő Szolgálat - PMKMSZ); ${ }^{5}$

- Zala Special Rescue Team (in Hungarian:Zala Különleges MentőkEgyesület-ZKM); ${ }^{6}$

- Hungarian Red Cross (in Hungarian: Magyar Vöröskereszt - VK); ${ }^{7}$

- Search-Rescue and Fire-Fighting Association of Pécs (in Hungarian: Pécsi KutatóMentő és Tüzoltó Egyesület - Pécs KMTE); ${ }^{8}$

- Volunteer Firefighters and Life Saving Association of Kaposvár (in Hungarian: Kaposvári Önkéntes Tűzoltó és Életmentő Egyesület - KÖTÉL). ${ }^{9}$

The members of the units are volunteers with special skills and experience of several years or even a decade. The staff include physicians, veterinary surgeons, paramedics, nurse practitioners, psychologists, dog handlers, firefighters, joiners, cavers, industrial alpinists, static engineers, explosives experts, heavy rigging and hazardous substance specialists. One part of the staff obtained their INSARAG classification back in November 2005 during a classification exercise held at the previous military base in Lenti-Zajda, Hungary. These rescue teams had been deployed several times earlier, which had justified their role in disaster relief. [4: 5]

The professional members of HUSZÁR have had numerous opportunities to utilise their skills when saving human lives and material goods. The volunteer firefighters of Pilis ÖTE, Pécs KMTE and KÖTÉL work closely together with the official national

\footnotetext{
Official website: http://vorosvartuzi.hu/

Official website: https://kutato-mento.hu/

Official website: http://zala.katasztrofavedelem.hu/zala-kulonleges-mentok-egyesulete

Official website: http://voroskereszt.hu/

Official website: www.rescue-pecs.hu/

Official website: http://kotelmento.hu/
} 
disaster management service, thus they contribute to citizens' safety on a daily basis. The members of PMKMSZ have several years of experience in the field of alpinism and dog search. They primarily work in the capital of Hungary and Pest County, but their search dogs have a global reputation as well. The Hungarian Red Cross have four representatives in the medical component of the team, who have full-time jobs in hospitals or at the ambulance services. Eighty percent of the members of ZKM works for official law enforcement bodies, so they also use their specialised knowledge and skills on a daily basis.

By examining the composition and previous interventions of the units and the volunteers we drew the conclusion that the high-level versatility of HUSZÁR is due to the fusion of the know-how of the individual, classified units.

The unique individual skills and the daily practice of the personnel provide a solid base for the operation of a medium USAR team. The UN INSARAG guidelines recommend the following arrangement and composition for a medium USAR team:

Table 1. The recommended arrangement and composition for medium USAR teams. [2: 35]

\begin{tabular}{|c|c|c|c|}
\hline $\begin{array}{c}\text { USAR } \\
\text { Component }\end{array}$ & Tasks & $\begin{array}{c}\text { Suggested } \\
\text { Staff Allocation }\end{array}$ & $\begin{array}{l}\text { Suggested } \\
\text { Number } \\
\text { (Total 40) }\end{array}$ \\
\hline \multirow[t]{7}{*}{ Management } & Command & Team Leader & 1 \\
\hline & Coordination & Deputy Team leader & 1 \\
\hline & Planning/Follow Up & Planning Officer & 1 \\
\hline & Liaison/Media/Reporting & Liaison Officer & 1 \\
\hline & Assessment/Analysis & Structural Engineer & 1 \\
\hline & Safety and Security & Safety Officer & 1 \\
\hline & RDC/OSOCC/UCC & Coordination Officer & 2 \\
\hline \multirow[t]{3}{*}{ Search } & Technical Search & Technical Search Specialist & 2 \\
\hline & Dog Search & Dog Handler & 2 \\
\hline & Hazardous Materials Assessment & $\begin{array}{l}\text { Hazardous Materials } \\
\text { Specialist }\end{array}$ & 2 \\
\hline \multirow[t]{2}{*}{ Rescue } & $\begin{array}{l}\text { Breaking and Breaching; cutting; shoring; } \\
\text { technical rope }\end{array}$ & $\begin{array}{l}\text { Rescue Team Manager and } \\
\text { Rescue Technicians }\end{array}$ & $\begin{array}{l}14 \text { ( } 2 \text { teams } \\
\text { comprising } 1 \\
\text { Team Leader and } \\
6 \text { Rescuers) }\end{array}$ \\
\hline & Lifting and Moving & Heavy Rigging Specialist & 2 \\
\hline \multirow[t]{2}{*}{ Medical } & \multirow{2}{*}{$\begin{array}{l}\text { Medical Team Management: Coordination } \\
\text { and administration of medical team. } \\
\text { Integration with local health infrastructure } \\
\text { Care of team (including canines) and victims } \\
\text { encountered }\end{array}$} & Medical Doctor & 1 \\
\hline & & $\begin{array}{l}\text { Physician, Paramedic, } \\
\text { Nurse }\end{array}$ & 3 \\
\hline \multirow[t]{5}{*}{ Logistics } & $\mathrm{BoO}$ & Logistics Team Manager & 1 \\
\hline & Water supply & Transport Specialist & 1 \\
\hline & Food supply & Logistician & 1 \\
\hline & Transport capacity and fuel supply & Base Manager & 2 \\
\hline & Communications & Communications Specialist & 1 \\
\hline
\end{tabular}


T. HÁBERMAYER, P. HORVÁTH: Voluntary Rescue Service in Hungary: The HUSZÁR Team

Composition of the HUSZÁR personnel in the 2017 re-classification:

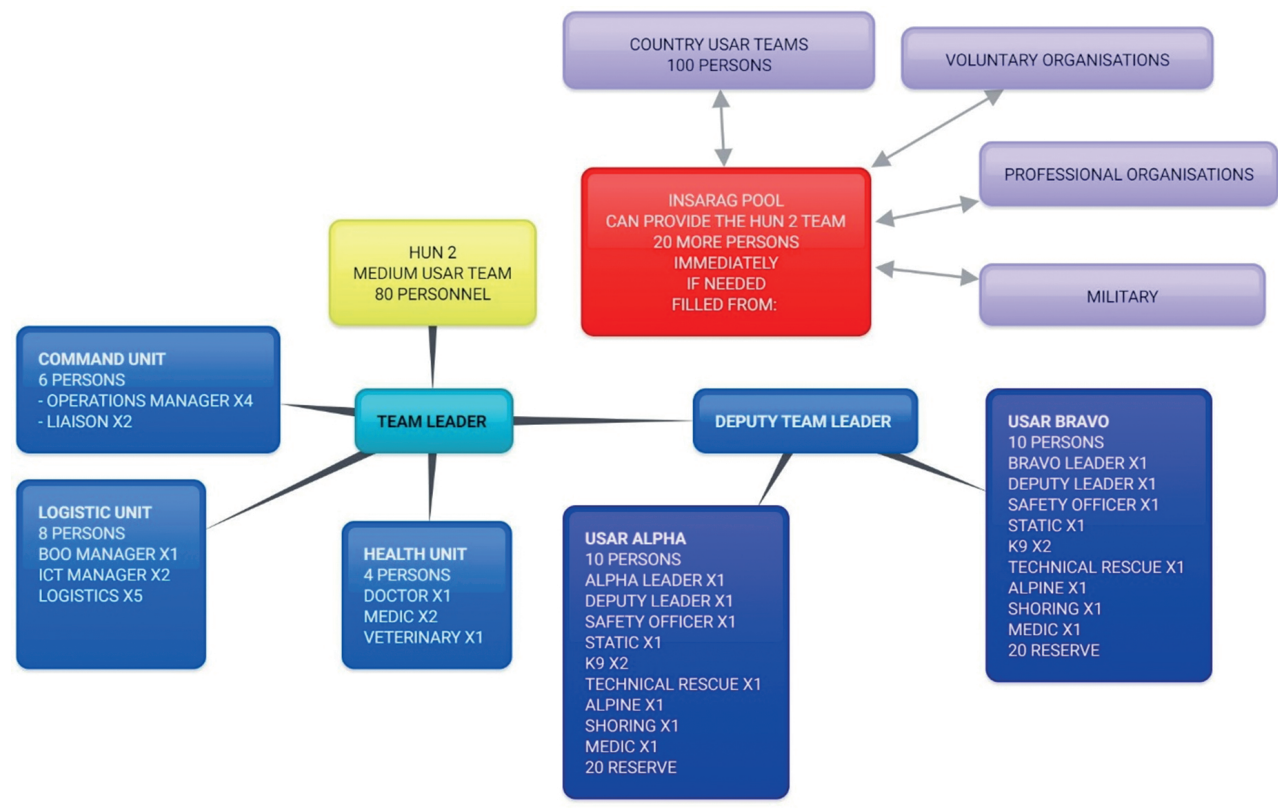

Figure 1. HUSZÁR staff. [Edited by the authors.]

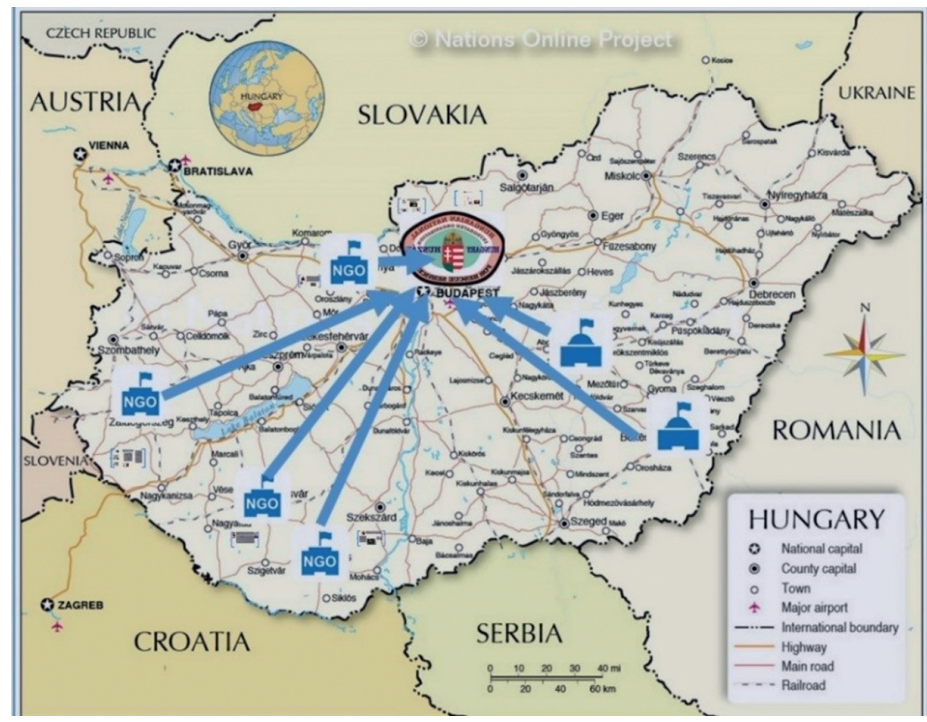

\begin{tabular}{|c|}
\hline DISTRIBUTION OF \\
HUNZ UNITS \\
BASE: \\
SZENTENDRE \\
UNITS: \\
SZENTENDRE \\
PILISVÖRÏSVÁR \\
ZALAEGERSZEG \\
KAPISVÁR \\
PÉES \\
SZDLNDK \\
BÉKÉSCSABA \\
\end{tabular}

Figure 2. Location of HUSZÁR units. [Edited by the authors.] 
The capabilities of HUSZÁR are summarised in this INSARAG Team Fact Sheet:

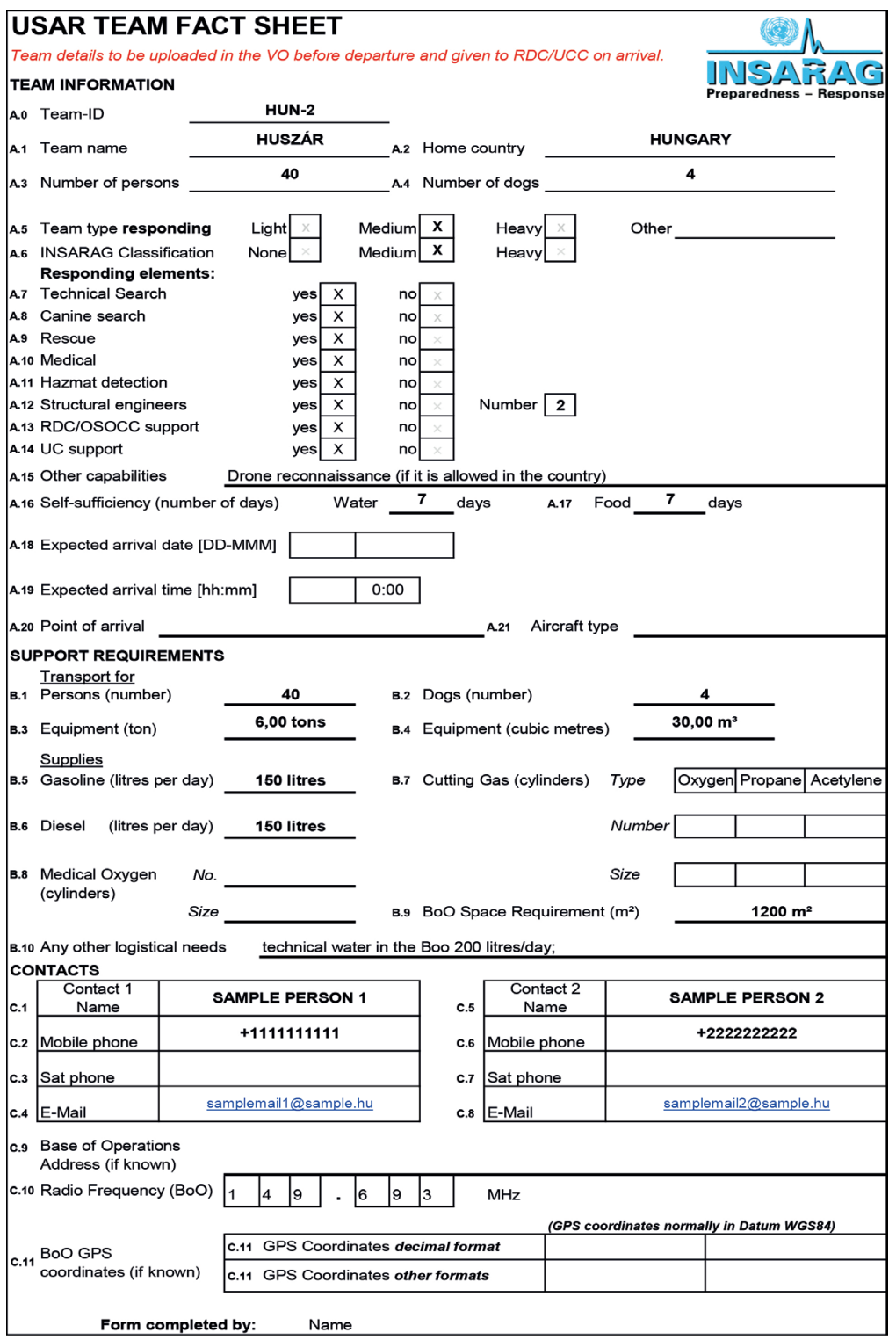

Figure 3. HUSZÁR Team Fact Sheet. [5]

[Completed by the authors.]

The figure shows that the rescue team has all the necessary structural (management, search, rescue, medical and logistic) components set forth by the INSARAG guidelines.

In Hungary the units are located a few hundred kilometres from each other. Their primary objective is the aversion of local hazards; however, they regularly exercise together and share all the experience they gain from individual deployments. 
The equipment necessary for international deployment is stored at the base of PMKMSZ in Budapest and on the premises of the subunits. Some equipment has two sets. This arrangement saves a lot of time in case of an occasional international deployment (air transport) since the transport will be sent from the Liszt Ferenc International Airport in Budapest. Should deployment be required in another region of the country, the domestic coverage of the whole country means that individual regional units can get to the scene of the event faster and they can start the initial survey earlier. By using the tools and devices operated by the units, search and rescue tasks can be commenced immediately and the other units can join in when they arrive. Cooperation between the units is continuous, which allows for joint financing or joint submission of tenders for new equipment. The units also exercise or take part in field practices together, thereby creating a strong and effective team that can fulfil the INSARAG guidelines and have a valid registration among the international USAR teams.

In summary, we can say that the individual and combined professional knowledge and skills of the units, which they use continuously, on a daily basis as part of their work, is an essential strength of the team in domestic and international disaster management tasks.

\section{Recommendations}

Properly executed volunteerism is a social value. It is important for the volunteers themselves as the society benefits from the positive effects of the activity, and it provides the volunteers with valuable feedback. This feedback helps the members of the voluntary organisations to remain engaged and motivated during the performance of their rescue operations. It has also been noted that a higher level of cooperation between volunteers is associated with the involvement of more professionals, which exerts a further positive effect on innovative capacity. Innovation results in novel, faster and more effective solutions during the interventions, which brings further success and recognition, thereby increasing motivation. Therefore, we recommend the further, more thorough investigation of voluntary organisations that have excellent performance and results in a specific field of activity (e.g. cave rescue, dog search, alpine techniques, etc). As part of the investigation, special attention has to be paid to the application of innovative technology as well as the acquisition of special interventional methods, since these can improve the efficiency and cost-effectiveness of official, governmental bodies.

No matter which national or international urban search and rescue team we talk about, belonging to any of them is significant honour, professional recognition and considerable responsibility as well. Working in such a special setting involves several challenges and the time factor of 100 hours exerts a strong influence on performance. Therefore, the training of rescue teams has to be continuous, focusing on special skills, equipment, as well as the culture of individual countries and regions. Apart from that, bridging linguistic and procedural differences is also essential for international coordination since an extensive earthquake, for instance, will certainly lead to severe damage with several interventional sites, and local INSARAG rescue teams will definitely need to be involved. As technology advances, the application of electric devices (which also necessitates further skills and trainings) can be of great assistance, since they can markedly improve the efficiency of 
interventions. Under the aegis of the United Nations, all rescue teams follow the INSARAG guidelines as the common platform of coordination, and the working language of action is English. This background information probably explains why being a member of such a team is considered to be of great honour by the volunteers. Besides high-level professional skills, team members obviously have to fulfil an ever-increasing number of requirements (e.g. language skills, application of electric devices, coordination in an international setting). Leaders have to face even higher expectations as they need:

- outstanding professional, IT and linguistic skills, as well as stress tolerance;

- significant creativity and improvisation skills;

- managerial, communication and coordination skills;

- familiarity with international protocol;

- dedication and motivation to represent their own country.

It has to be stated that not everybody is suitable for these operations, as most of the tasks are performed under extreme (and hazardous) conditions, which needs conscious preparation. When interventional planning takes place, sound competition does occur among the members, and all leaders aim to send their best experts to the site of international rescue operations. There is no legal hierarchy between the international rescue teams, only cooperation, since effectivity requires coordinated operations. When INSARAG principles are applied properly, the team is led by the most competent person, who is accepted by everybody else. All operations need outstanding professional, IT and linguistic skills; stress tolerance; creativity; managerial, communication and coordination skills; familiarity with international protocol, as well as dedication and motivation at the same time. The most essential guideline is that assistance has to be truly helpful rather than constituting further difficulties for the countries in need. US INSARAG sample forms have an electronic version as well, which can be uploaded in the Kobo Toolbox system and used instead of or parallel to the paper-based version. This will create a common, effective system of all participating groups, and all qualified teams will be able to perform professional tasks together on the basis of the common platform.

\section{References}

[1] MUHORAY Á.: Katasztrófamegelözés I. Budapest, NKE Szolgáltató Nonprofit Kft., 2016. https://ludita.uni-nke.hu/repozitorium/bitstream/handle/11410/10287/ebook_XL_KVI_ Katasztrofamegelozes_I.pdf?sequence=1\&isAllowed=y (Downloaded: 20.02.2019)

[2] 2011. évi CXXVIII. törvény a katasztrófavédelemröl és a hozzá kapcsolódó egyes törvények módosításáról. www.fao.org/faolex/results/details/en/c/LEXFAOC129205 (Downloaded: 12.02.2019)

[3] INSARAG Guidelines. Volume II: Preparedness and Response. Chapeau Manual A: Capacity Building. New York, United Nations Office for the Coordination of Humanitarian Affairs, 2015. http://portal.undac.org/pssuportal/portalrest/filesharing/ download/public/7FBS4Bt4kuozXvN (Downloaded: 12.02.2019) 
T. HÁBERMAYER, P. HORVÁTH: Voluntary Rescue Service in Hungary: The HUSZÁR Team

[4] JACKOVICS P.: Társadalmi és civil szervezetek szerepe a polgári-, és katasztrófavédelem tükrében. www.vedelem.hu/files/UserFiles/File/konf2007/pv/Jackovics_doc.pdf (Downloaded: 12.02.2019)

[5] INSARAG - Team Fact Sheet. www.insarag.org/images/Documents_and_forms/ USAR_Team_Fact_Sheet.pdf (Downloaded: 03.06.2020) 